\title{
Dependence of pea root mass distribution on weather conditions under varying levels of phosphorus application
}

\author{
Agnieszka Klimek-Kopyra ${ }^{1}$ and Krzysztof Rębilas ${ }^{2}$ \\ ${ }^{1}$ Institute of Plant Production, ${ }^{2}$ Department of Physics, \\ University of Agriculture in Kraków, Al. Mickiewicza 21, 31-120 Kraków, Poland \\ Received December 13, 2017; accepted April 30, 2018
}

\begin{abstract}
The aim of the study was to describe the distribution of pea root mass in the soil, over a three-year period, under varying weather conditions and at different levels of phosphorus application, by means of evaluating and comparing parameters of a mathematical model characterising cumulative root mass distribution. A two-factor experiment was conducted in Prusy, near Krakow: the first factor was the level of phosphorus application (0-70-140 $\left.\mathrm{kg} \mathrm{P}_{2} \mathrm{O}_{5} \mathrm{ha}^{-1}\right)$ and the second was the cultivars (six cultivars were tested). Experimental data produced using the model indicated that the root distribution was strongly differentiated by water availability in the years of the study. This appeared in some cases to be a more important factor than phosphorus application rates. The estimated soil depth at which $50 \%$ of the root mass was accumulated differed significantly for the dry and the wet year. In the wet year, only very high phosphorus application rates contributed to an increase in root mass distribution. The estimation of root mass distribution from the presented data can be used to improve phosphorus application depending on the amount of precipitation.
\end{abstract}

Keywords: root mass distribution, root distribution model, phosphorus application, legume

\section{INTRODUCTION}

The root system of plants of the Fabaceae family plays an important role in agricultural systems, as it improves the physicochemical properties of the soil, enriches biological life and contributes to the increase of nitrogen in the soil (Lynch, 1995). Owing to the development of a strong root system, legume plants can extract water from deeper soil layers. However, variances exist between legume species. For perennial crops, alfalfa shows the deepest rooting profile - with $95 \%$ of all roots in the $136 \mathrm{~cm}$ of soil (Canadell et al., 1996). For annual crops, soybean shows deeper rooting depth than other crops, with $95 \%$ of all roots occurring in

\footnotetext{
*Corresponding author e-mail: krzysztof.rebilas@ur.krakow.pl
}

the top 100-138 cm (Huck et al., 1986), wheras pea, chickpea, and lentil, have the shallowest rooting profile of annual crops, with $95 \%$ of all roots obtaining $64-85 \mathrm{~cm}$ in the top (Armstrong et al., 1994; Gregory, 1988; Liu et al., 2011). Legume seed production, when compared to cereals which are more resistant to variability, is also hampered due to high inter-annual yield differences caused by unpredictable weather conditions (Cernay et al., 2015). High variability in yield is generated by the specific response of plants to soil conditions and rainfall distribution, which causes disturbances in plant development (Klimek-Kopyra et al., 2016; Podleśny and Podleśna, 2011). Thus, the weather anomalies observed in recent years make it difficult to accurately predict crop yield due to periods of precipitation alternating with drier periods.

Unpredictable weather conditions necessitate the search for new, more plastic legume morphotypes in terms of root system development. Over the last few years, hence, a great deal of research has been conducted to evaluate root systems, mainly of cereals - barley, wheat and maize (Chloupek et al., 2010; Gao et al., 2015; Thorup-Kristensen et al., 2009), and less frequently of legumes - primarily bean, chickpea and soybean, and rarely pea (Gutierrez-Boem and Thomas, 1999; Naumann et al., 2010; Purushothaman et al., 2017).

In situ root monitoring in soybean cultivars in association with drought tolerance is known from the recent literature (Cseresnyés et al., 2016). The authors used indirect monitoring of root activity in soybean cultivars under contrasting moisture regimes by measuring electrical capacitance. Another approach to roots analysis was presented by Gardner (1960), Bruckler et al. (2004) and Vrugt et al. (2001). Research here has been based on image analysis,

(C) 2018 Institute of Agrophysics, Polish Academy of Sciences 
in one, two or three dimensions, taking into account various root, soil and plant parameters. However, as pointed out by Javaux et al. (2008), models should describe root development in a more real environment. In 2015, Heppell et al. (2015) found that the method of root image analysis could be used to define plant responses to deficit conditions, while Fan et al. (2016) demonstrated that the creation of models of root distribution in the soil profile is a more effective tool for evaluating root development. Still, only a handful of studies have been conducted on the modelling of pea root systems, mainly in Canada (Cutforth et al., 2013; Gan et al., 2009, 2011), Australia (Armstrong et al., 1994) and the USA (Williams et al., 2013). There are no studies, however, characterising the response of the root system of pea to weather conditions and varied fertilisation in central Europe.

The distribution of plant root systems clearly changes over the course of vegetative development, but it also does so under different environmental conditions. Ho et al. (2005), for example, demonstrated that the same species may exhibit varied plasticity in different soil conditions. In their work, the authors showed that plant (bean) cultivars demonstrated a great variation that was characterised by the utilisation of different strategies depending on habitat conditions. They noted that some cultivars form a shallower root system are better adapted to low levels of phosphorus, while cultivars with a deeper root system are more resistant to short-term droughts. There is also a third group of plants that exhibit a bidirectional response to abiotic stress, adapting to both drought and a limited supply of phosphorus.

Root activity is believed to play a role in the efficient use of water (Passioura, 1994). In a study by Gallardo et al. (1996), lupin (cv. Gungurru), despite having a smaller root system than wheat, maintained its water status due to greater root hydraulic conductivity (cv. Kulin). A crop with higher root hydraulic conductivity will generally have less difficulty extracting water from depth than a plant with similar characteristics but lower hydraulic conductivity (Taylor and Klepper, 1978). Passioura (1994) proposed using species or cultivars with lower root hydraulic conductivity to conserve water in extremely dry conditions, as in conditions of limited water, a crop with lower root hydraulic conductivity will extract soil water more gradually, thereby stabilising yield.

Hinsinger et al. (2011) suggest that there is still little information on the response of the root system of legumes, including peas, to different precipitation conditions, even though numerous root system-water models have been developed (Javaux et al., 2008; Doussan et al., 2006; Bruckler et al., 2004; Vrugt et al., 2001).

The aim of the study was to test a model evaluation of the root mass distribution in the soil for selected pea cultivars depending on varied rainfall and phosphorus application.

\section{MATERIALS AND METHODS}

A three-year field experiment (2013-2015) was conducted on Haplic Phaeozem in the Experimental Station of Agriculture University in Prusy, near Krakow ( $47^{\circ} 24^{\prime} \mathrm{N}$ lat., $7^{\circ} 19^{\prime} \mathrm{E}$ long., $300 \mathrm{~m}$ a.s.1.). The soil characteristics were as follows: $\mathrm{pH}$ 5.6, content of $\mathrm{P}_{2} \mathrm{O}_{5} 9.4 \mathrm{mg} 100 \mathrm{~g}^{-1}, \mathrm{~K}_{2} \mathrm{O} 11.1$ $\mathrm{mg} 100 \mathrm{~g}^{-1}$, total $\mathrm{C}$ and total $\mathrm{N}$ in the topsoil reached $2.03 \%$ and $0.129 \%$, respectively, while Corg. content was 3.49 . The cation exchange capacity (CEC) of soil obtained 150 mmol (+) $\mathrm{kg}^{-1}$.

A two-factor field experiment was developed in a randomised block design. The first factor was the level of phosphorus application (0-70-140 kg $\left.\mathrm{P}_{2} \mathrm{O}_{5} \mathrm{ha}^{-1}\right)$ and the second was cultivar choice. Six cultivars of pea (Pisum sativum L.) were tested; four edible cultivars (Protecta, Tarchalska, Batuta and Mecenas), and two forage (Tinker and Model). The plot size was $(1.25 \times 8) 10 \mathrm{~m}^{2}$ for each cultivar, wtih rows spaced $25 \mathrm{~cm}$ apart.

The forecrop each year was a winter wheat, and in the autumn, the soil was ploughed to a depth of $30 \mathrm{~cm}$. Before sowing, mineral fertilisers were applied and the soil was treated with cultivator. The nitrogen was applied at the starter rate of $30 \mathrm{~kg} \mathrm{ha}^{-1}$, while the potassium dose amounted to $100 \mathrm{~kg} \mathrm{~K}_{2} \mathrm{O} \mathrm{ha}^{-1}$ and the phosphorus was applied at two doses (70 and $140 \mathrm{~kg} \mathrm{P}_{2} \mathrm{O}_{5} \mathrm{ha}^{-1}$ ). The sowing was done each year in the last ten days of March, at $15 \mathrm{~cm}$ spacing, utilising a seed drill. Roots for the test purposes were collected in the first 10 days of July.

Root architectural traits of the pea plants were determined at mid-vegetative stages (flowering), and we limited our study to the soil profile with the highest level of root activity $(0-50 \mathrm{~cm})$, in accordance with Fan et al. (2016) and Armstrong et al. (1994). In the full flowering stage (midJuly), soil samples with roots were taken at four steps by means of a $15 \mathrm{~cm}$ long soil sampler, from the humus profile of the soil, and then divided into five parts, each $10 \mathrm{~cm}$ long $(0-50 \mathrm{~cm})$. Ten soil samples for each treatment, together with the pea roots, were collected with an Eijkelkamp root auger $7.5 \mathrm{~cm}$ in diameter and $15 \mathrm{~cm}$ long. Individual samples with roots were subsequently washed in an automatic hydropneumatic root washer fabricated at the Department of Crop Production in Kraków. The device is supplied with tap water, with an average efficiency of $2 \mathrm{dm}^{3} \mathrm{~min}^{-1}$, and compressed air at a pressure of 100-300 $\mathrm{kPa}$. The rinsing cycle for one sample takes $3 \mathrm{~min}$ and comprises two steps: $2 \mathrm{~min}$ at an air pressure of about $100 \mathrm{kPa}$ and then $1 \mathrm{~min}$ with the pressure increased to $300 \mathrm{kPa}$.

The cleaned root samples from each level were preserved in $25 \% \mathrm{v} / \mathrm{v}$ ethanol solution and stored for detailed analysis using APHELION software. After scanning, the roots were weighted and dried. The results were then used to determine the dry weight of the roots.

Finally, based on seed yield, phosphorus uptake per one tonne of seeds was calculated for the maturity stage (Moll et al., 1982). 
Table 1. Weather conditions during the pea vegetative period

\begin{tabular}{|c|c|c|c|c|c|c|c|}
\hline Year & & Decade & March & April & May & June & Mean/Total \\
\hline \multicolumn{8}{|c|}{ Temperature $\left({ }^{\circ} \mathrm{C}\right)$} \\
\hline \multirow[t]{10}{*}{$1981-2010$} & \multirow[b]{2}{*}{2013} & & 3.1 & 8.7 & 14.0 & 16.8 & \multirow[b]{2}{*}{13.5} \\
\hline & & 1 & 2.0 & 1.0 & 14.7 & 15.5 & \\
\hline & & 2 & -2.7 & 9.1 & 15.5 & 19.6 & \multirow[b]{3}{*}{13.5} \\
\hline & \multirow{3}{*}{2014} & 3 & -3.3 & 14.5 & 12.0 & 17.1 & \\
\hline & & 1 & 4.1 & 9.3 & 11.3 & 17.0 & \\
\hline & & 2 & 7.3 & 7.3 & 12.2 & 11.1 & \multirow{5}{*}{13.1} \\
\hline & \multirow{4}{*}{2015} & 3 & 8.3 & 13.9 & 17.1 & 13.9 & \\
\hline & & 1 & 2.9 & 4.3 & 13.2 & 19.0 & \\
\hline & & 2 & 3.9 & 9.5 & 13.1 & 17.4 & \\
\hline & & 3 & 6.7 & 11.8 & 12.6 & 15.5 & \\
\hline \multicolumn{8}{|c|}{ Precipitation (mm) } \\
\hline \multirow[t]{10}{*}{$1981-2010$} & \multirow{4}{*}{2013} & & 32.0 & 33.0 & 58.0 & 69.0 & \multirow{4}{*}{332.0} \\
\hline & & 1 & 4.6 & 11.8 & 55.0 & 139.0 & \\
\hline & & 2 & 10.0 & 6.2 & 8.3 & 23.5 & \\
\hline & & 3 & 20.0 & 2.1 & 35.5 & 50.6 & \\
\hline & \multirow[t]{3}{*}{2014} & 1 & 3.1 & 5.4 & 9.7 & 8.4 & 230.0 \\
\hline & & 2 & 26.9 & 19.0 & 83.0 & 26.1 & \multirow{5}{*}{181.8} \\
\hline & & 3 & 0.7 & 18.6 & 14.3 & 45.5 & \\
\hline & \multirow[t]{3}{*}{2015} & 1 & 0.4 & 16.5 & 46.3 & 0 & \\
\hline & & 2 & 13.9 & 0.4 & 28.4 & 17.3 & \\
\hline & & 3 & 24.8 & 25.3 & 29.1 & 18.5 & \\
\hline
\end{tabular}

During the run of the experiment, the average temperature and total precipitation were obtained from an automatic field weather station in Prusy, which is owned by the Department of Crop Production of the University of Agriculture in Kraków. Meteorological measurements were taken during the period of pea root system growth, i.e. from emergence to the flowering stage (April-July). Water requirements for peas in this period, according to Dzieżyc (1970), are 46, 74, and $80 \mathrm{~mm}$ for April, May and June, respectively. However, weather conditions varied in the years of the study (Table 1). In 2013, May and June were relatively wet in relation to pea requirements, while 2014 was very wet, mainly due to abundant and frequent rainfall during the growing season, but the total rainfall corresponded to the water requirement for peas. In the following year, 2015, however, very few days with precipitation were recorded for the entire growing period. Hence, this year can be considered as a drought or dry year in the three-year run of the study.

A model proposed by Schenk and Jackson (2002) was used to describe the cumulative root mass distribution $Y(d)$ as a function of the soil depth $d$. The curve given by the formula:

$$
Y(d)=\frac{m(d)}{m_{\max }}=\frac{1}{1+\left(\frac{d}{d_{50}}\right)^{c}},
$$

was fitted to the experimental data for the six cultivars of pea. In equation $m(d)$ is the cumulative amount of the root mass to soil depth $d, m_{\max }$ denotes the total mass of root, $d_{50}$ is the depth at which $50 \%$ of total root amount was accumulated, $c$ is a dimensionless shape-parameter. The three parameters $m_{\max }, d_{50}$ and $c$ were established by using the least-square fitting of equation to the experimental data. The fitting procedure was done using the Wolfram Mathematica computing system.

\section{RESULTS}

The experimental data for six cultivars of pea cultivated at different fertilisation doses of phosphorus $(0,70$, and $140 \mathrm{~kg}$ $\mathrm{P}_{2} \mathrm{O}_{5}$ ha $^{-1}$, respectively) during the years 2013, 2014 and 2015 , as well as the results of the respective fits of the curve given by equation to the data are shown in Fig. 1. Each experimental point represents the average mass of roots obtained from four items. 


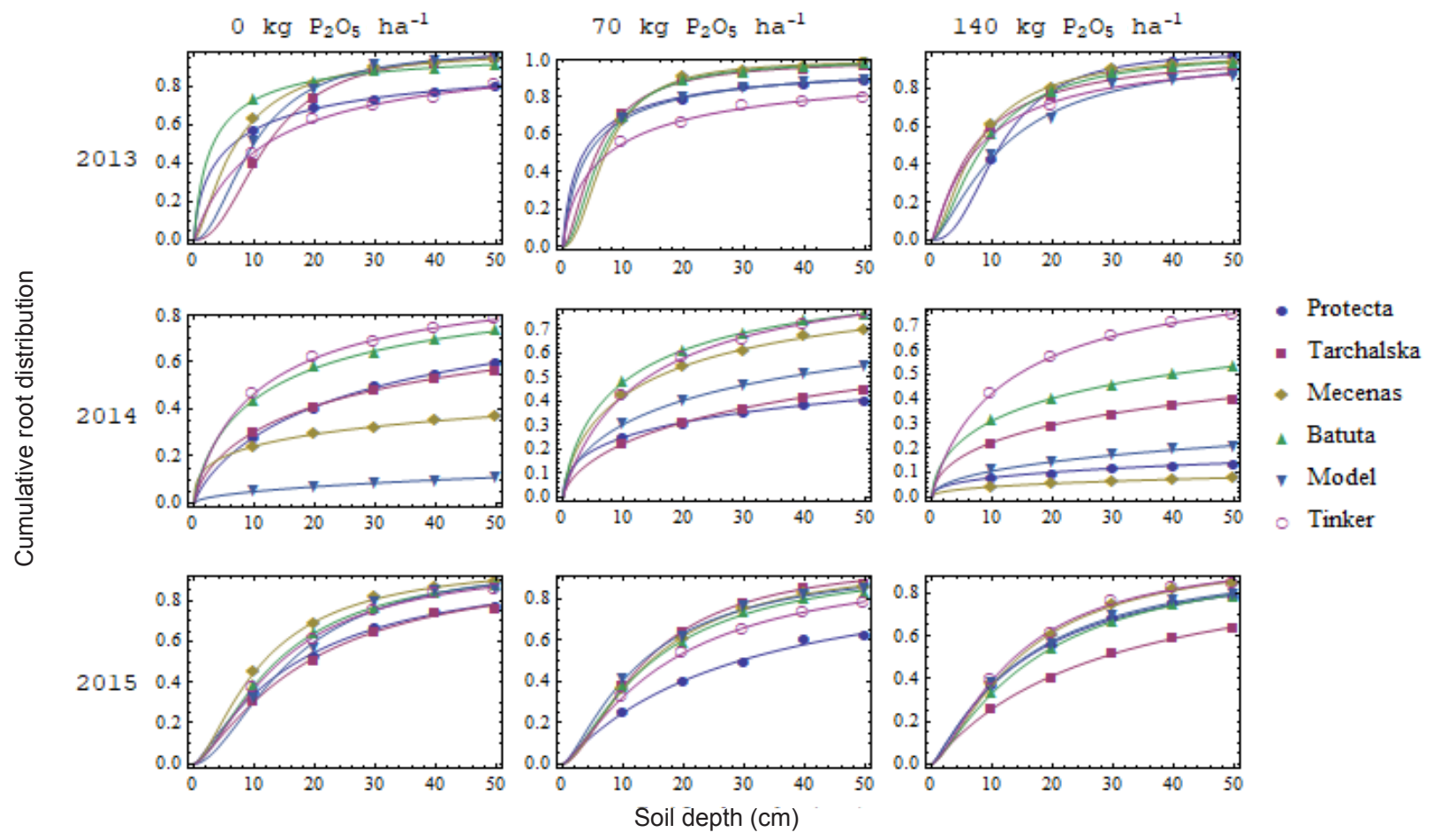

Fig. 1. Cumulative root distribution of pea cultivars as a function of soil depth and phosphorus dose: the experimental data and the fit of the curve (1).

Table 2. Values of the parameters $m_{\max }, d_{50}$, and $c$ achieved by means of the least square fitting of the curve given in equation to the experimental data

\begin{tabular}{|c|c|c|c|c|c|c|c|c|c|c|}
\hline \multirow{3}{*}{ Year } & \multirow{3}{*}{$\begin{array}{l}\text { Pea } \\
\text { cultivar }\end{array}$} & \multicolumn{9}{|c|}{ Phosphorus dose } \\
\hline & & \multicolumn{3}{|c|}{$0 \mathrm{~kg} \mathrm{P}_{2} \mathrm{O}_{5} \mathrm{ha}^{-1}$} & \multicolumn{3}{|c|}{$70 \mathrm{~kg} \mathrm{P}_{2} \mathrm{O}_{5} \mathrm{ha}^{-1}$} & \multicolumn{3}{|c|}{$140 \mathrm{~kg} \mathrm{P}_{2} \mathrm{O}_{5} \mathrm{ha}^{-1}$} \\
\hline & & $\begin{array}{c}m_{\max } \\
\left(\mathrm{g} \mathrm{cm}^{-3}\right)\end{array}$ & $\begin{array}{c}d_{50} \\
(\mathrm{~cm})\end{array}$ & $c$ & $\begin{array}{c}m_{\max } \\
\left(\mathrm{g} \mathrm{cm}^{-3}\right)\end{array}$ & $\begin{array}{c}d_{50} \\
(\mathrm{~cm})\end{array}$ & $c$ & $\begin{array}{c}m_{\max } \\
\left(\mathrm{g} \mathrm{cm}^{-3}\right)\end{array}$ & $\begin{array}{c}d_{50} \\
(\mathrm{~cm})\end{array}$ & $c$ \\
\hline \multirow{6}{*}{2013} & Protecta & 0.001 & 6.40 & 0.679 & 0.002 & 3.41 & -0.796 & 0.0007 & 11.3 & -2.36 \\
\hline & Tarchalska & 0.001 & 12.1 & -2.19 & 0.001 & 5.55 & -1.59 & 0.002 & 7.00 & -1.18 \\
\hline & Mecenas & 0.001 & 6.86 & -1.42 & 0.001 & 7.02 & -2.08 & 0.002 & 7.39 & -1.50 \\
\hline & Batuta & 0.002 & 3.10 & -0.852 & 0.001 & 6.36 & -1.81 & 0.001 & 8.67 & -1.57 \\
\hline & Model & 0.002 & 9.84 & -1.92 & 0.002 & 4.19 & -0.875 & 0.001 & 11.9 & -141 \\
\hline & Tinker & 0.001 & 11.8 & -0.947 & 0.001 & 7.46 & -0.757 & 0.002 & 9.15 & -1.07 \\
\hline \multirow{6}{*}{2014} & Protecta & 0.007 & 30.09 & -0.822 & 0.010 & 116 & -0.449 & 0.029 & $5.31 \times 10^{3}$ & -0.390 \\
\hline & Tarchalska & 0.006 & 33.3 & -0.685 & 0.008 & 66.8 & -0.655 & 0.007 & 102 & -0.535 \\
\hline & Mecenas & 0.008 & 209 & -0.373 & 0.004 & 15.5 & -0.718 & 0.040 & $1.98 \times 10^{4}$ & -0.410 \\
\hline & Batuta & 0.005 & 13.5 & -0.770 & 0.004 & 11.1 & -0.778 & 0.005 & 39.4 & -0.576 \\
\hline & Model & 0.030 & 65.9 & -0.535 & 0.006 & 36.9 & -0.635 & 0.014 & 714 & -0.497 \\
\hline & Tinker & 0.005 & 11.6 & -0.871 & 0.004 & 14.0 & -0.913 & 0.005 & 14.1 & -0.867 \\
\hline \multirow{6}{*}{2015} & Protecta & 0.002 & 17.0 & -1.20 & 0.004 & 29.2 & -1.02 & 0.003 & 15.7 & -1.16 \\
\hline & Tarchalska & 0.002 & 18.7 & -1.29 & 0.002 & 13.6 & -1.61 & 0.003 & 28.1 & -1.02 \\
\hline & Mecenas & 0.002 & 11.4 & -1.48 & 0.002 & 14.4 & -1.50 & 0.003 & 14.3 & -1.43 \\
\hline & Batuta & 0.002 & 13.5 & -1.52 & 0.003 & 14.8 & -1.38 & 0.002 & 17.3 & -1.27 \\
\hline & Model & 0.002 & 15.8 & -1.75 & 0.003 & 13.2 & -1.34 & 0.003 & 15.4 & -1.19 \\
\hline & Tinker & 0.002 & 14.2 & -1.50 & 0.003 & 17.6 & -1.26 & 0.003 & 13.6 & -1.40 \\
\hline
\end{tabular}




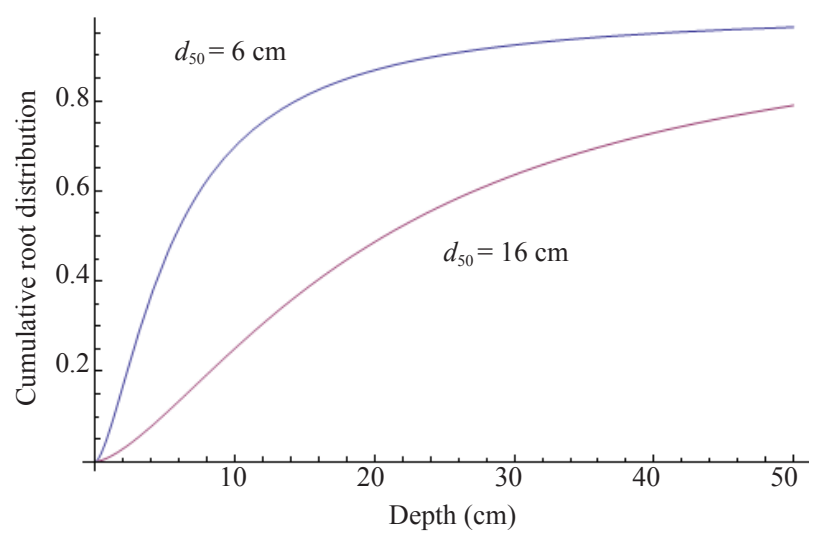

Fig. 2. Dependence of the cumulative root mass distribution $Y(d)$ on the depth $d$ (equation) for different values of the parameter $d_{50}$. The values of $d_{50}$ presented in the figure are chosen as an example. The figure shows qualitatively that for smaller values of $d_{50}$, the roots are cumulated nearer the soil surface.

Values of the parameters $m_{\max }, d_{50}$ and $c$ are collected in Table 2. The most informative parameters are $m_{\max }$ and $d_{50}$. The former represents the estimated total mass of the root and the latter characterises how evenly the roots are distributed in the soil. Figure 2 shows that, according to the curve given by equation, the greater $d_{50}$, the more homogenous is the roots displacement in the soil. Or, in other words, the smaller $d_{50}$, the more the roots are cumulated near the soil surface.

The pea root system exhibited a high degree of plasticity depending on the quantity and frequency of rainfall (Table 1).

In 2013, frequent rainfall (45 times in 3 months) resulted in a shallow pea root system for the control crop without phosphorus application $\left(d_{50}<12 \mathrm{~cm}\right.$, Fig. 1 and Table 1$)$, with 76-94\% of the root mass in the upper layer of the soil. The standard application of phosphorus $\left(70 \mathrm{~kg} \mathrm{P}_{2} \mathrm{O}_{5} \mathrm{ha}^{-1}\right)$, in essence, did not change the root distribution, making it only slightly more concentrated near the soil surface $\left(d_{50}\right.$ was slightly diminished for most cultivars). Only the high $\mathrm{P}$ application rate $\left(140 \mathrm{~kg} \mathrm{ha}^{-1}\right)$ increased the root mass distribution towards the deeper soil layers, which is reflected by the fact that the cumulative root distribution curve is less steep (Fig. 1) and the $d_{50}$ parameter is greater for most pea cultivars (Table 1). This effect may seem to indicate increased uptake of phosphorus, but this is not the case, as explained below.

In 2014, when the level of rainfall was optimal for the water requirements of pea and was distributed evenly over the period of root growth (April-June), greater root mass distribution was observed in the soil profile. High values obtained for the $d_{50}$ parameter indicate uniform root distribution in the soil profile. Moreover, increased phosphorus application resulted in a significant increase in the $d_{50}$ parameter, especially in the Tarchalska and Mecenas cultivars and in the fodder cultivars of pea (Model and Protecta), where $d_{50}$ is at more than $100 \mathrm{~cm}$. Compared to 2013, the cumulative root distribution in 2014 was considerably different for different cultivars of pea (Fig. 1), which shows that optimal conditions for plant development enable the root growth to be specific for the biological features of each cultivar.

In the dry year of 2015, with little precipitation during the pea root growth stage, the root mass distribution was similar in all crops regardless of phosphorus application. This indicates that additional phosphorus uptake was highly hindered in these conditions, with $50 \%$ of the root mass being within the surface soil layer, reaching the width between 11.4 and $29.2 \mathrm{~cm}$, which amounts to 41.4 to $77.2 \%$ of the total root mass in the soil. The presence of phosphorus in the soil contributed to greater root activity only for Protecta $\left(d_{50}\right.$ increased from 17.0 to $29.2 \mathrm{~cm}$ for P application rate of $\left.70 \mathrm{~kg} \mathrm{ha}^{-1}\right)$ and Tarchalska $\left(d_{50}\right.$ was enhanced from 18.7 to $28.1 \mathrm{~cm}$ for a $P$ application rate of $140 \mathrm{~kg} \mathrm{ha}^{-1}$ ), which resulted in an increase in the root mass in the deeper layers of the profile (Fig. 1). Similarly to the year 2013, in 2015 , the cumulative root distribution, in general, did not differ for the different pea cultivars. However, unlike 2013, the roots are not cumulated mainly in the shallow layer of the soil but are distributed more homogeneously. This is because in the dry year of 2015, plant roots tend to develop towards the deeper layers to reach for water. Nevertheless, the root growth in 2015 is more limited as compared to the optimal year of 2014 (generally, $d_{50}$ is much smaller for 2015, Table 1) due to restricted phosphorus uptake from the dry soil.

Phosphorus uptake by pea seed yield varied annually among the cultivars and phosphorus doses (Tables 3 and 4). A statistically significant increase in the phosphorus uptake with the increased dose of $\mathrm{P}_{2} \mathrm{O}_{5}$ was observed only between the control treatment $\left(0 \mathrm{~kg} \mathrm{P}_{2} \mathrm{O}_{5}\right.$ ha $\left.^{-1}\right)$ and the optimal treatment $\left(70 \mathrm{~kg} \mathrm{P}_{2} \mathrm{O}_{5}\right.$ ha $\left.^{-1}\right)$ and only for the wet year of 2013 (Table 3). Despite the fact that the roots distribution in 2013 became more homogenous for intensified fertilisation $\left(140 \mathrm{~kg} \mathrm{P}_{2} \mathrm{O}_{5}\right.$ ha $^{-1}$, Fig. 1), this did not lead to an increase in the plant $P$ uptake.

As for the dependence of the $\mathrm{P}$ uptake with changing precipitation (years), statistical differences were recorded only for the treatments with the fertiliser added and only between the wet year of 2013 and the optimal year of 2014 .

Table 3. Nutrient uptake $\left(\mathrm{kg} \mathrm{t}^{-1}\right)$ of $1 \mathrm{t}$ of pea seeds depending on phosphorus fertilization level

\begin{tabular}{cccc}
\hline & \multicolumn{3}{c}{ Phosphorus dose } \\
\cline { 2 - 4 } Year & $0 \mathrm{~kg} \mathrm{P}_{2} \mathrm{O}_{5} \mathrm{ha}^{-1}$ & $70 \mathrm{~kg} \mathrm{P}_{2} \mathrm{O}_{5} \mathrm{ha}^{-1}$ & $140 \mathrm{~kg} \mathrm{P}_{2} \mathrm{O}_{5} \mathrm{ha}^{-1}$ \\
\cline { 2 - 4 } & \multicolumn{3}{c}{ Nutrient uptake $\left(\mathrm{kg} \mathrm{t}^{-1}\right)$} \\
\hline 2013 & $5.538 \mathrm{aA}$ & $6.151 \mathrm{~b} \mathrm{~A}$ & $6.076 \mathrm{~b} \mathrm{~A}$ \\
2014 & $5.218 \mathrm{a} \mathrm{A}$ & $5.049 \mathrm{a} \mathrm{B}$ & $5.128 \mathrm{a} \mathrm{B}$ \\
2015 & $4.869 \mathrm{a} \mathrm{A}$ & $4.827 \mathrm{a} \mathrm{B}$ & $4.969 \mathrm{a} \mathrm{B}$ \\
\hline
\end{tabular}

Statistical differences between: phosphorus fertilization - small letters, years (precipitation) - capital letters (Tukey test, $\alpha=0.05$ ). 
Table 4. Nutrient uptake $\left(\mathrm{kg} \mathrm{t}^{-1}\right)$ of $1 \mathrm{t}$ of pea seeds depending on cultivar type

\begin{tabular}{|c|c|c|c|}
\hline \multirow[t]{2}{*}{ Cultivar } & 2013 & 2014 & 2015 \\
\hline & \multicolumn{3}{|c|}{ Nutrient uptake $\left(\mathrm{kg} \mathrm{t}^{-1}\right)$} \\
\hline Batuta & $5.700 \mathrm{a}$ & 4.909 a & $5.261 \mathrm{~b}$ \\
\hline Mecenas & $5.657 \mathrm{a}$ & $4.744 \mathrm{a}$ & $4.839 \mathrm{ab}$ \\
\hline Protecta & $5.778 \mathrm{ab}$ & $4.804 \mathrm{a}$ & $4.589 \mathrm{ab}$ \\
\hline Tinker & $6.209 \mathrm{bc}$ & $5.402 \mathrm{ab}$ & $5.075 \mathrm{ab}$ \\
\hline Model & $6.680 \mathrm{c}$ & $6.000 \mathrm{~b}$ & $5.180 \mathrm{ab}$ \\
\hline Tarchalska & $5.579 \mathrm{a}$ & $4.929 \mathrm{a}$ & $4.386 \mathrm{a}$ \\
\hline
\end{tabular}

Letters express statistical differences between cultivars (Tukey test, $\alpha=0.05)$.

The highest uptake of $\mathrm{P}\left(6.076 \mathrm{~kg} \mathrm{t}^{-1}\right)$ was noted in the wet year of 2013, and essentially decreased with decreasing precipitation. Among the different cultivars, the most notable Model was the one for which the P uptake was always significantly greater for the wet year 2013 and almost always (save its relation to Tinker) for the year 2014.

\section{DISCUSSION}

Most of the existing mathematical models present the results of studies on the root mass distribution conducted under controlled conditions, and do not adequately reflect the natural behaviour of roots. Moreover, they fail to take into account the heterogeneity of the soil environment and weather conditions. Schenk and Jackson (2002), for example, showed that root mass distribution can be evaluated more accurately in the natural environment of plants than in controlled laboratory conditions. Williams and Ehleringer (2000) noted that a description of root mass distribution should take into account not only the total amount of water, but also the distribution of rainfall during the growing period. What is more, Cseresnyes et al. (2014) indicated that legume symbiosis with arbuscular mycorrhizal (AM) fungi can substantially affect root development, root mass distribution and root activity, particularly when associated with phosphorus supply. For this reason, Schenk and Jackson (2002) propose taking into account local environmental conditions of plant growth, including periods of rainfall and drought, organic matter content, and the plant species. In their work, the authors showed that average $50 \%$ rooting depths $\left(d_{50}\right)$ for global vegetation varied between $5 \mathrm{~cm}$ and $28 \mathrm{~cm}$. These results suggest that at least half of the root mass is located in the upper soil layer (upper $30 \mathrm{~cm}$ ). At the same time, the root mass distribution can be further diversified as a result of varying amounts of nutrients.

The model presented in our study showed that weather conditions, mainly the distribution of rainfall during the flowering stage (maximum root mass), are a key element of the distribution of root mass in the soil profile. In the year that had a large amount of rainfall (2013), the root mass distribution in the soil profile was more shallow and became more homogenous only after application of higher levels of phosphorus. In the year with less rainfall (2015), the roots developed toward the moist, deeper layer in the soil and therefore were distributed more evenly, with no variation in the amount of phosphorus added to the crop. This shows that the phosphorus uptake was strongly limited in these conditions.

Armstrong et al. (1994) tested the development of pea roots under controlled water deficit conditions. The authors showed that most of the compared cultivars formed 80-97\% of their root mass in the soil layer down to $20 \mathrm{~cm}$. Only the Wirrega genotype had greater root mass distribution, due to greater substrate moisture - a difference of about $40 \mathrm{~cm}$ of root distribution between the genotypes. The authors also showed variation between fodder and narrow-leafed cultivars. Fodder varieties make significantly better use of soil water resources through more heterogeneous root mass distribution in the soil. These findings were confirmed to some extent in our own study. The fodder cultivars in the year with optimum distribution of precipitation for the development of the plants were characterised by high root system activity, resulting in a greater root mass below $20 \mathrm{~cm}$ of the profile for the high rate of $\mathrm{P}$ application.

Variation in the root mass development among species and within a given species is discussed extensively by Fageria and Moreira (2011). A vigorous root system is essential in conditions of water or nutrient deficiency (Hoad et al., 2001). Breeders creating new varieties of pea should improve not only their quantitative characteristics (yield), but also the distribution of roots in the soil profile, so as to utilise water and nutrient resources more efficiently. Our study showed that root mass distribution varies depending on the amount of water and phosphorus. In conditions of frequent rainfall during the growing period, the use of high phosphorus application rates, above $70 \mathrm{~kg} \mathrm{ha}^{-1}$, was necessary to increase the roots distribution in the soil.

Candrakova et al. (2014) demonstrated that phosphorus uptake with pea seed yield is related to weather conditions and dose of fertilisation. According to the authors, phosphorus uptake is the highest in a wet year, whereas the lowest total nutrient uptake is in a drought year due to the lack of soil moisture and high temperature, thereby limiting the function of the root system. Aditionally, they revealed that the highest uptake of $\mathrm{P}$ was found in the control treatments. Our study showed that the phosphorus uptake with one tonne of seed yield was significantly related to the availability of water in soil. The highest $P$ uptake was noted in the wet year of 2013 and decreased for the years 2014 and 2015 which came with less rainfall. In turn, from our results, it follows that there is no difference between the control and the treatment with fertiliser for the years 2014 (optimal precipitation) and 2015 (the dry year). Only in the wet year of 2013 did the fertisation significantly improve the P uptake as compared to the control treatment.

As for the P uptake for different cultivars our results showed that there was no distinguished cultivar (with the exception of Model). Table 4 indicates that in general the 
data obtained for the nutrient uptake do not differ significantly. The root distribution (Fig. 1) also appeared to be very similar for all cultivars for the years 2013 and 2015. The observed differentiation in the root distribution in the year 2014 seems to be, then, related to the individual properties of cultivars, and this could only have been revealed under optimal conditions. Still, this variable had no direct impact on the P uptake.

Our research showed that water is a nutrient carrier and is responsible for the root mass distribution in the soil profile. It is worth noting that despite the fact that according to agricultural standards concerning precipitation, the year 2014 can be regarded as optimal, the wet year of 2013 appeared to be superior with regard to plant phosphorus uptake. At the same time, the root distribution in 2013 was very shallow for all cultivars (Fig. 1) in contrast to the more evenly allocated roots in the year 2014, which, nevertheless, did not lead to an increased P uptake in 2014. This shows that root distribution cannot be regarded as a decisive factor determining the root effectiveness in the process of taking up phosphorus from soil.

\section{CONCLUSIONS}

1. The model, together with the estimated parameters, was revealed to be the appropriate tool for characterising the effects of water limitation during the growing season, as well as soil phosphorus level.

2. The root mass distribution in the soil depends strongly on the amount of precipitation. In the wet year, the roots were distributed mainly near the surface for all pea cultivars. In the dry year, the roots of all cultivars exhibited a tendency to be distributed more evenly in the soil. This distribution was very similar for all cultivars. Under optimal conditions, the root distribution was much more differentiated and reflected the individual properties of each cultivar.

3. The results suggest that in regions characterised by droughts and semi-droughts, increased phosphorus application is not recommended, as it may not affect the distribution of the roots and the $\mathrm{P}$ uptake.

4. The phosphorus uptake cannot be related uniquely to the roots distribution in the soil profile.

Conflict of interest: The Authors do not declare conflict of interest.

\section{REFERENCES}

Armstrong E.L., Pate J.S., and Tennant D., 1994. Patterns of water use and root growth in genotypes of contrasting morphology and growth habit. Funct. Plant Biol., 21, 517-532.
Bruckler L., Lafolie F., Doussan C., and Bussieres F., 2004. Modeling soil-root water transport with non-uniform water supply and heterogeneous root distribution. Plant Soil, 260, 205-224.

Canadell J., Jackson R.B., Ehleringer J.B., Mooney H.A., Sala O.E., and Schulze E.D., 1996. Maximum rooting depth of vegetation types at the global scale. Oecologia, 108, 583-595.

Candrakova E., Andrejcikova M., and Hanackova E., 2014. Yield formation of common peas and nutrient uptake. Res. J. Agric. Sci., 46, 109-116.

Cernay C., Ben-Ari T., Pelzer E., Meynard J.-M., and Makowski D., 2015. Estimating variability in grain legume yields across Europe and the Americas. Sci. Rep., 5, 11171.

Chloupek O., Dostal V., Streda T., Psota V., and Dvorackova O., 2010. Drought tolerance of barley varieties in relation to their root system size. Plant Breed., 129, 630-636.

Cseresnyés I., Rajkai K., and Takács T., 2016. Indirect monitoring of root activity in soybean cultivars under contrasting moisture regimes by measuring electrical capacitance. Acta Physiologiae Plantarum, 38(5), 109-121.

Cseresnyés I., Takács T., Fuzy A., and Rajkai K., 2014. Simultaneous monitoring of electrical capacitance and water uptake activity of plant root system. Int. Agrophys., 28, 537-541.

Cutforth H.W., Angadi S.V., McConkey B.G., Miller P.R., Ulrich D., Gulden R.,Volkmar K.M., Entz M.H., and Brandt S.A., 2013. Comparing rooting characteristics and soil water withdrawal patterns of wheat with alternative oilseed and pulse crops grown in the semiarid Canadian prairie. Can. J. Soil Sci., 93, 147-160.

Doussan C., Pierret A., Garrigues E., and Pages L., 2006. Water uptake by plant roots: II. Modelling of water transfer in the soil root-system with explicit account of flow within the root system: Comparison with experiments. Plant Soil, $183,99-117$.

Gallardo M., Eastham J., Gregory P.J., and Turner N.C., 1996. A comparison of plant hydraulic conductances in wheat and lupins. J. Exp. Bot., 47, 233-239.

Gan Y., Liu L., Cutforth H., Wang X., and Ford G., 2011. Vertical distribution profilesand temporal growth patterns of roots in selected oilseeds, pulses and spring wheat. Crop Pasture Sci., 62, 457-466.

Gan Y.T., Campbell C.A., Janzen H.H., Lemke R., Liu L.P., Basnyat P., and McDonald C.L., 2009. Root mass for oilseed and pulse crops: Growth and distribution in the soil profile. Can. J. Plant Sci., 89, 883-893.

Gao K., Chen F., Yuan L., Zhang F., and Mi G., 2015. A comprehensive analysis of root morphological changes and nitrogen allocation in maize in response to low nitrogen stress. Plant Cell Environ., 38, 740-50. doi: 10.1111/ pce. 12439

Gardner W.R., 1960. Dynamic aspects of water availability to plants. Soil Sci., 89, 63-73.

Gregory P.J., 1988. Root growth of chickpea, faba bean, lentil, and pea and effects of water and salt stresses. In: World Crops: Cool Season Food Legumes (Ed. R.J. Summerfield). Springer, Netherlands.

Gutierrez-Boem F. and Thomas G., 1999. Phosphorus nutrition and water deficits in field-grown soybeans. Plant Soil, 207, 87-96. 
Fageria N.K. and Moreira A., 2011. The Role of Mineral Nutrition on Root Growth of Crop Plants. In: Advances in Agronomy (Ed. D.L. Sparks), Academic Press, Newark, USA.

Fan J., McConkey B., Wang H., and Janzen H., 2016. Root distribution by depth for temperate agricultural crops. Field Crop Res., 189, 68-74.

Heppell J., Talboys P., Payvandi S., Zygalakis K.C., Fliege J., Withers P., Jones D., and Roose T., 2015. How changing root system architecture can help tackle a reduction in soil phosphate (P) levels for better plant $\mathrm{P}$ acquisition. Plant Cell Envi., 38, 118-128.

Hinsinger P., Brauman A., Devau N., Jourdan C., Laclau J., Le Carde E., Jaillard B., and Plassard C., 2011. Acquisition of phosphorusand other poorly mobile nutrients by roots. Where do plant nutrition models fail? Plant Soil, 348, 29-61.

Ho M., Rosas J., Brown K., and Lynch J., 2005. Root architectural tradeoffs for water and phosphorus acquisition. Fun. Plant Biol., 32, 737-748.

Hoad S.P., Russell G., Lucas M.E., and Bingham I.J., 2001. The management of wheat, barley, and oat root systems. Adv. Agron., 74, 193-254.

Huck M.G., Peterson C.M., Hoogenboom G., and Busch C.D., 1986. Distribution of dry matter between shoots and roots of irrigated and nonirigated determinate soybeans. Agron. J., 78, 807-813.

Javaux M., Schroder T., Vanderborght J., and Vereecken H., 2008. Use of a three-dimentional detailed modeling approach for predicting root water uptake. Vadose Zone J., 7, 1079-1088.

Klimek-Kopyra A., Skowera B., Zając T., and Grygierzec B., 2016. Development and production response of edible and forage varieties of pea (Pisum sativum L.) to temporary soil drought under different levels of phosphorus application. Acta Agrobot., 69, 1663-1676.

Liu L., Gan Y., Bueckert R., and Van Rees K., 2011. Rooting systems of oilseed and pulse crops. II. vertical distribution patterns across the soil profile. Field Crop Res., 122, 248-255.

Lynch J., 1995. Root architecture and plant productivity. Plant Physiol., 109, 7-13.
Moll R.H., Kamprath E.J., and Jackson W.A., 1982. Analysis and interpretation of factors which contribute to efficiency to nitrogen utilization. Agron. J., 74, 562-564.

Naumann A., Heine G., and Rauber R., 2010. Efficient discrimination of oat and pea roots by cluster analysis of Fourier transform infrared (FTIR) spectra. Field Crop Res., 119, 78-84.

Passioura J.B., 1994. The yield of crops in relation to drought. (Eds K.J. Boote, J.M. Bennett, T.R. Sinclair, G.M. Paulsen). Physiology and determination of crop yield. ASA, CSSA, SSSA, Madion, WI, USA.

Podleśny J. and Podleśna A., 2011. Effect of rainfall Mount and distribution on growth, development and Fields of determinate and indeterminate cultivars of blue lupine. Pol. J. Agr., 4, 16-22.

Purushothaman R., Krishnamurthy L., Upadhyaya H.D., Vadez V., and Varshney R., 2017. Genotypic variation in soil water use and root distribution and their implications for drought tolerance in chickpea. Fun. Plant Biol., 44, 235-252.

Schenk H.J. and Jackson R.B., 2002. The global biogeography of roots. Ecol. Monogr., 72, 311-328.

Taylor H.M. and Klepper B., 1978. The role of rooting characteristics in the supply of water to plants. Adv. Agon., 30, 99 128.

Thorup-Kristensen K., Cortasa M.S., and Loges R., 2009. Winter wheat roots grow twice as deep as spring wheat roots, is this important for $\mathrm{N}$ uptake and $\mathrm{N}$ leaching losses? Plant Soil, 322, 101-114.

Vrugt J.A., van Wijk M.T., Hopmans J.W., and Šimunek J., 2001. One-, two-, and three-dimensional root water uptake functions for transient modeling. Water Resour. Res., 37, 2457-2470.

Williams D.G. and Ehleringer J.R., 2000. Intra- and interspecific variation for summer precipitation use in pinyon-juniper woodlands. Ecological Monographs, 70, 517-537.

Williams J.D., McCool D.K., Reardon C.L., Douglas C.L., Albrecht S.L., and Rickman R.W., 2013. Root:shoot ratios and belowground biomass distribution for Pacific Northwest dry land crops. J. Soil Water Conserv., 68, 349-360. 